\title{
PENINGKATAN KUALITAS DAN DAYA SAING PRODUK USAHA JAJANAN KHAS LOMBOK DI DESA SURADADI KABUPATEN LOMBOK TIMUR
}

\author{
Muhammad Zainul Majdi ${ }^{1 *}$, Baiq Yuliana Rizkiwati ${ }^{1)}$, dan Rasyid H. Wirasasmita ${ }^{2)}$ \\ 1) Program Studi Pendidikan Ekonomi, Universitas Hamzanwadi \\ 2) Program Studi Pendidikan Informatika, Universitas Hamzanwadi
}

Jalan TGKH Muhammad Zainuddin Abdul Madjid No. 132 Pancor, Kab. Lombok Timur

*alamat korespondensi: m.zainulmajdi@gmail.com

\begin{abstract}
ABSTRAK
Kegiatan pengabdian kepada masyarakat ini bertujuan untuk meningkatkan kualitas dan daya saing produk Usaha Mikro Kecil di Desa Suradadi Kabupaten Lombok Timur khususnya. Bentuk kegiatan yang dilakukan antara lain mengadakan pelatihan manajemen Usaha, meningkatkan kemampuan mitra dalam mendesain kemasan dan katalog produk, menerbitknan No-PIRT dan label halal, dan penggunaan internet sebagai media pemasaran. Kegiatan pengabdian kepada masyarakat inii dilaksanakan menggunakan metode ceramah, diskusi, demonstrasi, praktik langsung, observasi, serta sosialisasi, dan evaluasi. Pelaksanaan pengabdian kepada masyarakat pada skema Program Kemitraan Masyarakat (PKM) tahun anggaran 2018 meliputi tahapan pendahuluan, perencanaan, pelaksanaan, dan pelaporan. Adapun hasil kegiatan yang telah dilakukan yakni Pelatihan manajemen Usaha, Pelatihan manajemen keuangan, Pelatihan web dan pemasaran, Sosialisasi keamanan pangan dan legalitas usaha, terbitnya PIRT dan label halal untuk produk UKM Rinjani dan Sasakku, Katalog aneka jajanan khas Lombok dan Blog sebagai media pemasaran. Kegiatankegiatan tersebut terbukti sangat membantu mitra dengan memiliki pengetahuan dan keterampilan, menumbuhkan bahkan meningkatkan jiwa wirausaha, dari segi keamanan usaha pangan olahan lebih aman di konsumsi dan menjamin serta melindungi konsumen terhadap produk halal dan meningkatkan kepercayaan konnsumen, dengan katalog dapat memudahkan konsumen dalam memilih aneka jajanan yang akan di pesan, kemudian adanya blog dapat meningkatkan jaringan pemasaran dan memiliki jaringan yang lebih luas.
\end{abstract}

Kata kunci: usaha kecil menengah, aneka jajanan khas Lombok, Desa Suradadi, 


\section{PENDAHULUAN}

Hasil pendataaan Sensus Ekonomi tahun 2016 Provinsi Nusa Tenggara Barat (NTB) menunjukkan bahwa Kabupaten Lombok memiliki jumlah perusahaan yang paling banyak dibandingkan engan kabupaten lainnya di wilayah Provinsi NTB. Jumlah perusahaan di Kabupaten Lombok Timur sebanyak 149.318 (24,94 persen) perusahaan. Disusul Kabupaten Lombok Tengah dan Lombok Barat sebanyak 121.204 (20,24 persen) perusahaan dan 84.334 (14,09 persen) perusahaan, untuk kota mataram sebanyak 56,922 (9,51 persen), Kabupaten Bima sebanyak 53,263 (8,90 persen), Kabupaten Sumbawa sebanyak 42,337 (7,07 persen), kabupaten Lombok Utara sebanyak 28,552 $(4,77$ persen), kabupaten Dompu sebanyak 27,551 (4,60 persen), kota Bima sebanyak 21,831 (3,65 persen). Sementara itu, Kabupaten Sumbawa Barat paling sedikit jumlah perusahaan, yaitu hanya sebanyak 13.397 (2,24 persen) perusahaan.

\section{Berdasarkan Skala Usaha}

Mikro Kecil (UMK), jumlah perusahaan yang berada di wilayah Provinsi NTB paling banyak berada di Kabupaten Lombok Timur, yaitu mencapai 148.699 Usaha Mikro Kecil. Untuk kategori industri pengolahan jumlah yang tercatat adalah 38.011 unit dan mampu menyerap jumlah tenaga kerja sebesar 381.459 tenaga Kerja. Ini berarti Usaha Mikro Kecil memegang peranan penting dalam meningkatkan perekonomian masyarakat.

Keberadaan Usaha Mikro Kecil (UMK) industri pangan olahan di wilayah Lombok Timur ini berpotensi akan banyak memberikan manfaat bagi peningktan kesehjateraan masyarakat yang juga merupakan cita-cita dan tujuan dari pembangunan yang dilaksanakan oleh pemerintah daerah Lombok Timur. Kendati demikian, pertumbuhan Kabupaten Lombok Timur tersebut hanya sebesar 3,59\% dari sensus ekonomi 2006 lalu. Yang artinya UMK khusus industri pangan olahan di kabupaten Lombok Timur masih lemah.

Usaha Mikro Kecil (UMK) Industri pengolahan yang menjadi mitra I dalam kegiatan pengabdian kepada masyarakat ini adalah UMK Kelompok Industri pengolahan aneka jajanan khas Lombok dengan nama perusahaan "Rinjani" yang berada di desa Suradadi kecamatan Terara kabupaten Lombok Timur dan yang menjdai Mitra II UMK Kelompok Industri pengolahan aneka jajanan khas Lombok dengan nama Perusahaan "Sasakku" yang berada di desa Santong, kecamatan Terara Kabupaten Lombok Timur. Kedua UMK yang menjadi mitra adalah UMK kelompok Industri pengolahan aneka 
jajanan khas lombok "Rinjani" yang dimiliki oleh ibu Zuriatun (UMK I) dan UMK "Sasakku" yang dimiliki oleh ibu Mustiaji (UMK II). Produk industri pangan olahan dari kedua UMK ini menggunakan bahan baku beras dan beras Ketan. Pada waktu-waktu tertentu pelaku UMK jajanan khas Lombok sulit untuk mendapatkan bahan baku dari produknya tersebut dikarenakan faktor musim yang mengakibatkan harga jual bahan baku di pasaran menjadi tidak stabil serta kualitas yang dijual di pasar tidak semuanya memiliki kriteria yang sesuai standarisasi. Oleh karena itu pelaku UKM jajanan khas Lombok bekerjasama dengan pedagang yang ada di pasar untuk menyediakan bahan baku dengan kualitas yang baik dan sesuai dengan standarisasi yang telah ditentukan. Hal itu dilakukan untuk menjaga kualitas dari produk jajanan yang dihasilkan oleh pelaku UMK tersebut.

Kedua UMK tersebut saling bekerja sama, Terlihat bentuk kerjasama antara mitra I dan Mitra II terutama apabila UMK I tidak dapat memenuhi jumlah pesanan, maka sebagian order akan diberikan kepada Mitra II begitu juga sebaliknya. UMK I terdiri dari 3 orang anggota, dan UMK II terdiri dari 3 orang anggota. Seluruh anggota kelompok tersebut merupakan warga desa sekitar UMK berada, sehingga usaha industri pangan olahan aneka jajanan khas Lombok ini telah berhasil mengangkat perekonomian masyarakat desa sekitar UMK ini berada. Mitra mulai menekuni usaha pembuatan aneka jajanan khas Lombok ini sejak tahun 2004 sampai sekarang namun UMK ini belum bisa dikatakan berkembang karena produk yang dihasilkan belum mampu bersaing di pasar sehingga terbatasnya jumlah produksi yang menyebabkan pendapatan juga terbatas.

Ciri Khas dari produk Mitra I dan Mitra II yaitu; memproduksi aneka jajanan khas Lombok terdiri dari aneka jajanan kering dan aneka jajanan basah. Untuk aneka jajanan kering khas Lombok diantaranya; keciput, tarek, renggi, kaliadem, komak, bawang, tempeyek. Sementara untuk aneka jajanan basah khas Lombok diantaranya; wajik, banget, lupis, nagasari, tiken, serabi. Permintaan dari konsumen terus bertambah baik dari segi rasa dan variasi, tidak hanya memesan jajanan khas Lombok saja tetapi juga jajanan masa kini. Untuk memenuhi permintaan konsumen yang beraneka ragam, kedua mitra memproduksi aneka jajanan masakini sesuai dengan permintaan konsumen seperti; kue jahe, kue nastar, kuping gajah, kacang asin, kacang telur, kacang selimut, kacang pedas manis, stik bawang dan lain sebagainya. Aneka jajanan khas Lombok ini 
sangat digemari semua kalangan untuk dijadikan camilan pribadi, keluarga dan juga untuk suguhan tamu pada hari-hari besar. Jajanan khas Lombok ini jenisnya pun beragam mulai dari yang rasanya manis hingga gurih. Dengan harga pasaran yang murah dan terjangkau sehingga dapat menarik minat konsumen untuk mengkonsumsinya.

Produk mitra dipasarkan dengan harga yang beragam sesuai dengan bahan-bahan yang digunakan dalam pengolahan aneka jajanan tersebut. Untuk aneka jajanan kering dikemas dengan tiga ukuran yaitu; dengan ukuran kemasan $0,5 \mathrm{~kg}, 0,25$ $\mathrm{kg}$ dan ada juga yang eceran harga RP 1000. Dimana harga yang kemasan 0,5 kg dengan kisaran harga mulai dari Rp Rp 17.500 - Rp 30.000 ribu, dan harga untuk yang kemasan yang ukuran 0,25 kg dengan kisaran harga mulai dari Rp 8.500 - Rp 12.500 . Sementara untuk aneka jajanan basah biasanya dijual dengan dihitung perbiji dan dipasarkan dengan harga Rp. 1000 - Rp. 2.500 perbiji. Kedua mitra juga menerima pesanan khusus dari konsumen dalam jumlah yang banyak, disini akan dihitung 12 biji untuk setiap pebelian Rp 10.000.

Setiap bulan masing-masing mitra mampu mengolah aneka jajanan kering berkisar 120-180 kg dengan beraneka macam jenis jajanan. Dan untuk pesanan aneka jajanan basah berkisar 50-75 kg dengan beraneka macam jenis jajanan. Jumlah produksi setiap bulannya di sesuaikan dengan jumlah permintaan pasar. Adapun omset dari hasil penjualan aneka jajanan kering setiap bulanya berkisar $\mathrm{Rp}$ 2.400.000 - Rp 3.600.000, sementara omset dari hasil penjualan aneka jajanan basah setiap bulannya berkisar $\mathrm{Rp} 1.000 .000$ - $\mathrm{Rp}$ 1.500.000. Pemasaran produk dilakukan dengan dijual ke kios-kios, koperasi, lewat sales untuk didistribusikan ke pasar-pasar tradisonal, serta ada konsumen yang datang sendiri memesan produk aneka jajanan kering maupun yang basah ke rumah kedua mitra. Serta kedua mitra juga menerima pesanan untuk acara rapat kerja, acara mahasiswa, walimahan, tasyakurran dan acara-acara lainnya.

Usaha yang dijalankan kedua UMK ini merupakan usaha kelopmpok dan kepemilikan modal adalah modal kelompok. Manajemen yang dijalankan juga masih sederhana. Kedua UMK belum memiliki struktur organisasi yang baik, sehingga posisi anggota semuanya sama. Kedua UMK belum memiliki sistem pembukuan yang baik dan rapi, sehingga tidak tampak jelas keuntungan atau kerugian yang mereka dapatkan. Kedua UKM ini belum memiliki perizinan PIRT (Perizinan Industri Rumah Tangga) 
dan belum memiliki labelisasi halal MUI, Tampilan kemasan produk yang cukup sederhana sehingga terbatasnya pemasaran tidak sampai menembus pasaran modern.

Proses pembuatan aneka jajanan khas Lombok cukup bervariasi sesuai dengan jenis yang akan di buat. Adapun pembuatan secara umum, dimulai dengan mencampurkan semua bahan, campurkan air sedikit demi sedikit sambil diuleni sampai kalis. Tipiskan adonan sampai ketebalan yang diinginkan, dipotong kecil-kecil dan dibentuk sesuai bentuk yang diinginkan. Kemudian panaskan minyak goreng, dan goreng sampai berwarna coklat keemasan. Angkat dan siap untuk dikemas. Sebagian besar peralatan yang mendukung proses produksi sudah dimiliki oleh Mitra I dan Mitra II, sehingga mitra I dan mitra II, tidak hanya memproduksi aneka jajanan khas Lombok saja, namun kedua mitra juga banyak memproduksi aneka jajanan yang lainnya.

Hasil observasi yang telah dilakukan tim pengabdi mendapatkan keterangan bahwa Masalah yang dihadapi Mitra I dan Mitra II, yaitu;1) Manajemen usaha yang dijalankan masih sederhana, 2) Belum memiliki sistem pembukuan yang baik dan rapi, sehingga keuntungan maupun kerugian tidak dapat terdeteksi dengan baik, 3) belum memiliki perizinan PIRT (Pangan Industri Rumah Tangga), 4) belum memiliki lebelisasi halal dari MUI, 5) tampilan kemasan produk masih sangat sederhana sehingga tidak mampu bersaing dengan produk pangan di luar NTB yang kemasannya tampil menarik bagi konsumen. 6) Keterbatasan kemasan dalam satuan, 0,5 $\mathrm{Kg}$ dan 0,25 $\mathrm{Kg}$ dan kemasan eceran harga RP 1000, 7) Pemasaran terbatas di kios-kios, koperasi dan pasar tradisional menyebabkan produksinya terbatas, 8) Belum memiliki kemampuan dalam membuat desain katalog aneka jajanan untuk memudahkan konsumen melihat langsung aneka jajanan yang di produksi. 9) Jaringan pemasaran yang dimiliki sangat terbatas tidak bisa memasuki pasar moderen. 10) Belum memiliki kemampuan penggunaan Teknolgi Informasi sebagai media pemasaran sehingga omset yang diterima oleh mitra tidak maksimal.

Berdasarkan latar belakang yang telah diuraikan, maka kegiatan pengabdian kepada masyarakat ini akan dilaksanakan dalam berbagai bentuk, antara lain; adalah: 1) perbaikan sistem manajemen, 2) kepengurusan legalitas produk berupa kepemilikan perizinan Pangan Industri Rumah Tangga (PIRT) dan lebelisasi Halal MUI, 3)Peningkatan kemampuan dalam mendisain kemasan produk, 4) memiliki katalog 
produk aneka jajanan khas Lombok untuk memudahkan para pelanggan melihat langsung aneka jajanan yang akan dipesan 5) Penggunaan teknologi informasi sebagai media pemasaran produk. Adapun rencana kegiatan yang diusulkan untuk mencapai tujuan di atas maka kegiatan yang dilakukan melalui Kegiatan pengabdian kepada masyarakat ini adalah: 1) pelatihan manajemen, 2) kepengurusan legalitas produk berupa kepemilikan perizinan Pangan Industri Rumah Tangga (PIRT) dan lebelisasi Halal MUI, 3)Peningkatan kemampuan dalam mendisain kemasan produk, 4) memiliki katalog produk aneka jajanan khas Lombok untuk memudahkan para pelanggan melihat langsung aneka jajanan yang akan dipesan 5) Penggunaan teknologi informasi sebagai media pemasaran produk.

\section{METODE KEGIATAN}

Kegiatan ini dilaksanakan di desa Suradadi Kecamatan Terara Kabupaten Lombok Timur Provinsi Nusa Tenggara Barat. Metode yang digunakan yakni: ceramah, diskusi, demonstrasi, praktik langsung, observasi serta sosialisasi. Metode ceramah digunakan dalam proses penyampaian materi pelatihan. Disamping itu digunakan juga dalam memberikan motivasi kepada pengusaha untuk selalu bertahan dan meningkatkan semangat berusaha sebagai modal utama dalam meningkatkan daya saing para pengusaha industri pangan olahan. Metode diskusi digunakan sebagai media komunikasi saat pelatihan berlangsung sehingga terjadi komunikasi dua arah antara pemateri dan para pengusaha industri pangan olahan. Metode demonstrasi digunakan dalam proses memberikan contoh dalam setiap pelatihan, sehingga memberikan kemudahan kepada para pengusaha industri pangan olahan dalam memahami materi yang disampaikan. Metode praktik langsung digunakan untuk mengaplikasikan materi yang telah didapatkan, tentunya dengan bimbingan pemateri. Metode observasi dilakukan untuk mengamati kemampuan para pengusaha pangan olahan baik selama proses pelatihan maupun sesudah pelatihan. Sosialisasi dilakukan secara kolektif kepada para pengusaha untuk memberikan bekal ilmu bagaimana cara produksi makanan yang aman dan benar dengan kepemilikan Perizinan industry Rumah tangga (PIRT) dan labelisasi halal MUI. Pengamatan sesudah pelatihan ditujukan untuk mengetahui dampak dari pelatihan yang telah dilaksanakan terkait dengan kemajuan tingkat produktivitas dan daya saing para pengusaha pangan olahan. 


\section{HASIL DAN PEMBAHASAN}

Mengacu pada rencana

kegiatan yang telah dilaksanakan, didapatkan berbagai capaian sesuai dengan target luaran, adapun rincian jadwal kegiatan yang sudah dilakukan seperti ditunjukkan pada Tabel 1.

Tabel 1. Susunan kegiatan pengabdian kepada masyarakat

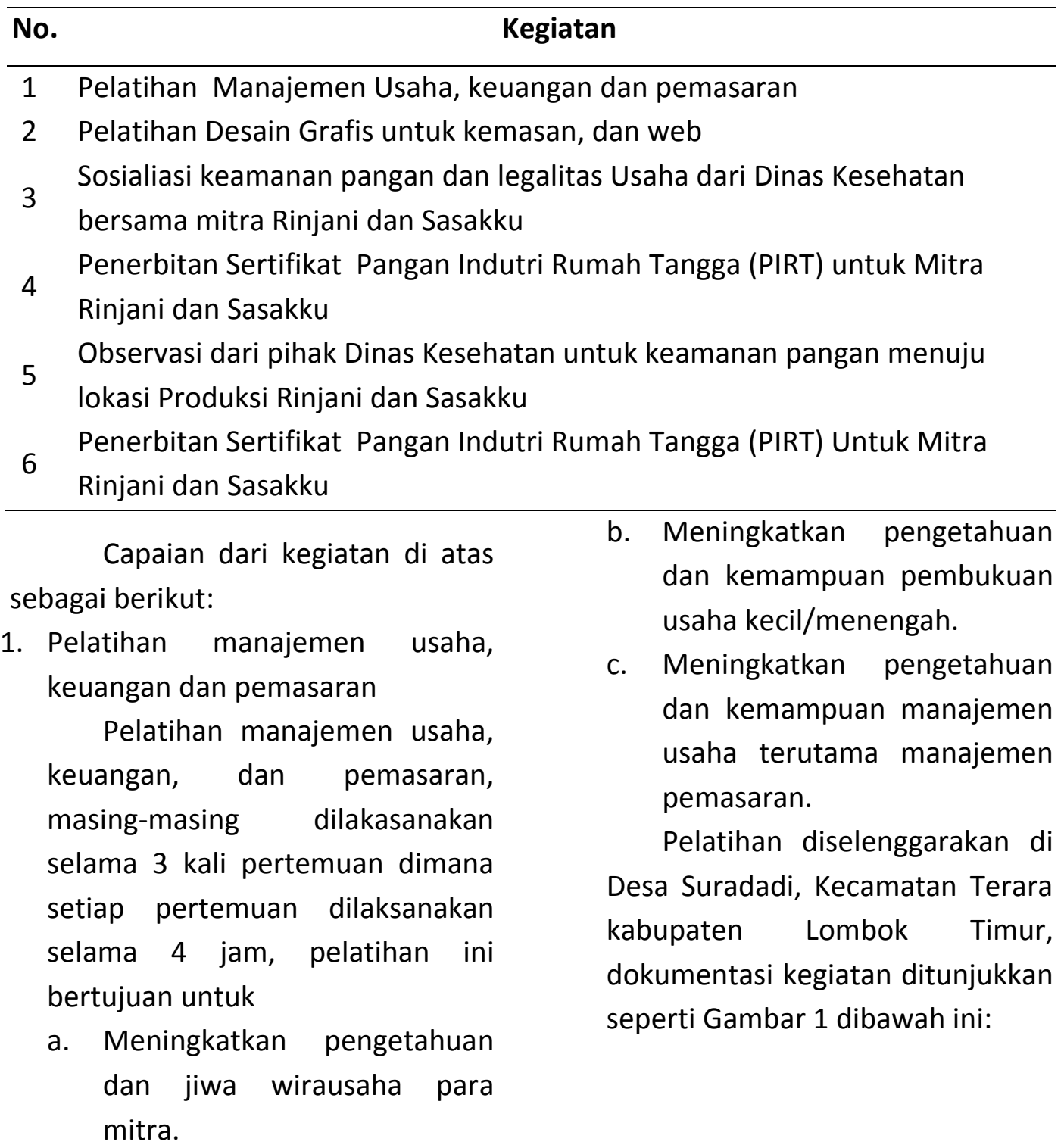




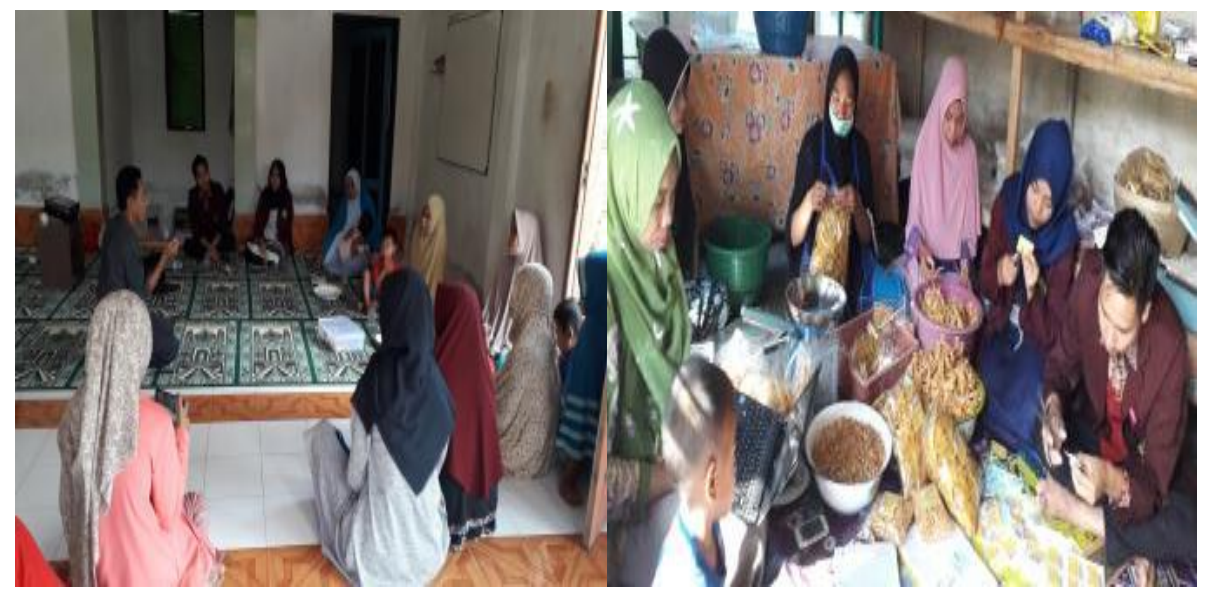

Gambar 1. Ringkasan Kegiatan pelatihan Manajemen Usaha, Keuangan, Disain dan Pemasaran

2. Kegiatan Penyuluhan dan Observasi Kesehatan dan Ketahanan Pangan dari Dinas Kesehatan Lombk Timur

Kegiatan ini bertujuan untuk mengajukan perizinan PIRT (Pangan Industri Rumah Tangga) yang akan dipergunakan untuk makanan yang memiliki daya tahan / keawetan di atas 7 hari yang akan masuk golongan makanan layak sehat.

Penyuluhan pentinganya ketahanan pangan dan pembuatan perizinan PIRT dan dilakasanakan selama 3 kali pertemuan dimana yang satu kali pertemuan dilaksanakan selama 4 jam, kemudian dilanjutkan dengan pendaftara Perizinan (PIRT), kegiatan ini bertujuan untuk :

a. Meningkatkan kepercayaan konsumen Dengan adanya periijin PIRT (Pangan Industri Rumah Tangga).

b. Meningkatkan jaringan pemasaran, dengan adanya perizinan PIRT maka industri pangan olahan siap bekerjasama dengan banyak orang untuk memasarkan produk. Adapun dokumentasi kegiatan ditunjukkan pada Gambar 2 dibawah ini: 


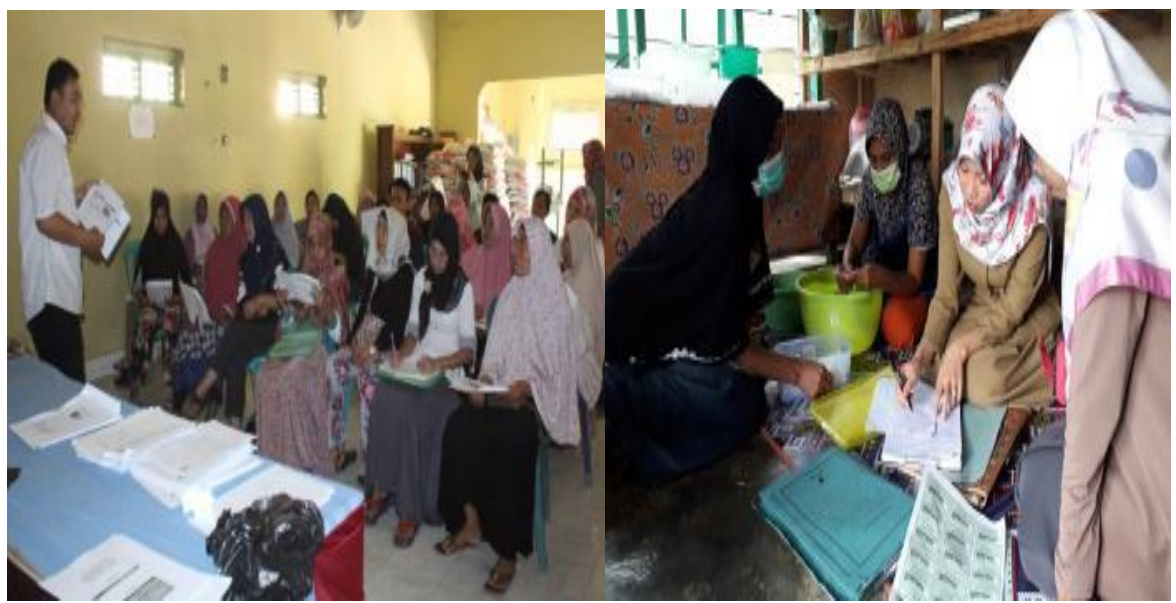

Gambar 2. Rincian Kegiatan Penyuluhan dan Observasi Keamanan Pangan dari Tim Dinas Kesehatan Lombok Timur

3. Kegiatan Penyuluhan dan Observasi dari LPPOM MUI Mataram Nusa Tenggara Barat

Kegiatan penyuluhan

labelisasi halal MUI penting untuk membedakan dan mengetahui produk-produk yang dihasilkan oleh pelaku usaha termasuk UMK dalam pemenuhan standar kehalalan sebagai makanan yang sehat, aman dan proporsional.
Penyuluhan dilakasanakan selama tiga kali pertemuan dimana yang satu kali pertemuan dilaksanakan selama empat jam, kemudian dilanjutkan dengan pendaftaran label halal produk. Adapun dokumentasi kegiatan ditunjukkan pada Gambar 3 dibawah ini:

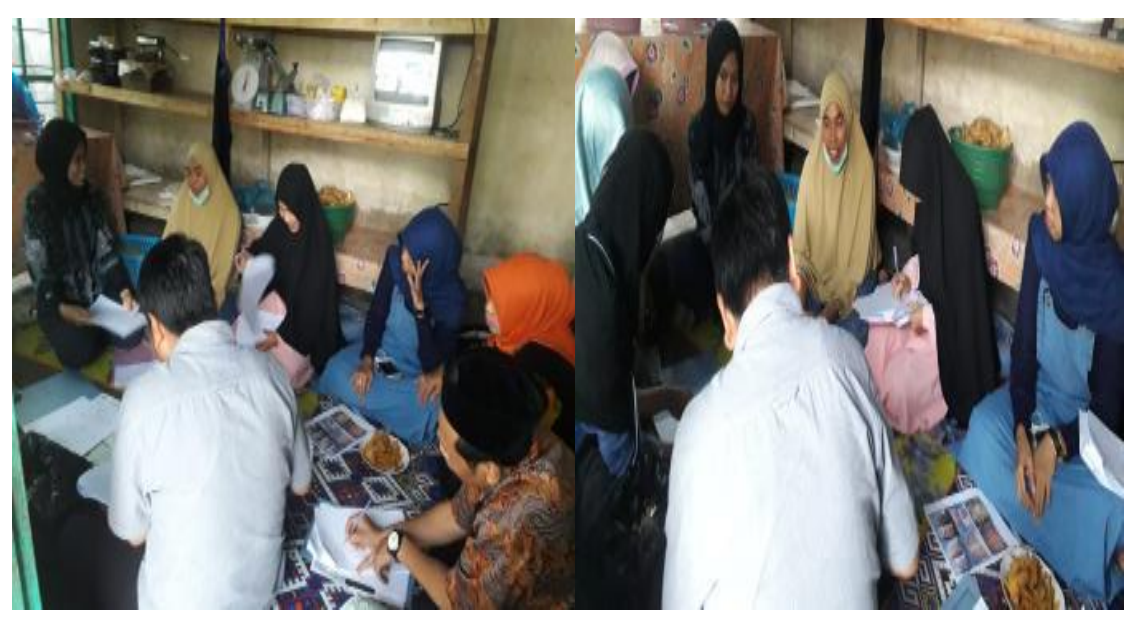


Gambar 3. Rincian Kegiatan Penyuluhan dan Observasi Keamanan Pangan dari Tim LPPOM MUI Nusa Tenggara Barat

4. Disain Stiker kemasan dan Katalog kerin dan basah yang biasa Produk Rinjani dan Sasakku

Disain kemasan produk yang dihasilkan mempunyai variasi ukuran dan bentuk yang pada akhirnya akan menambah kualiatas daya saing terhadap produk yang dihasilkan. Sedangkan untuk katalog diproduksi mitra. Katalog ini juga mempermudah bagi para konsumen dalam memilih aneka jajanan yang akan dipesan. Dokumentasi disain stiker dan katalog kedua UKM ditunjukkan pada Gambar 4 dan 5 dibawah ini: berisikan semua jenis aneka jajanan

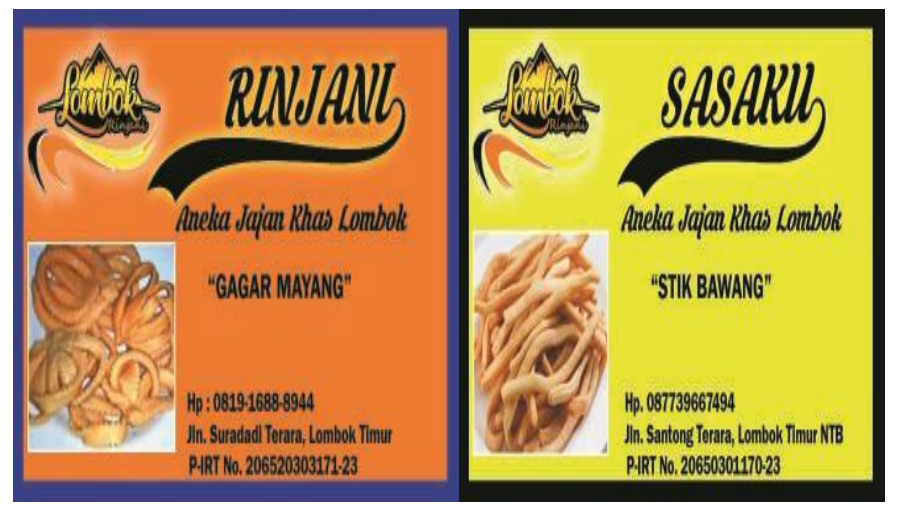

Gambar 4. Stiker Kemasan Produk Mitra Ukm Rinjani Dan Sasakku

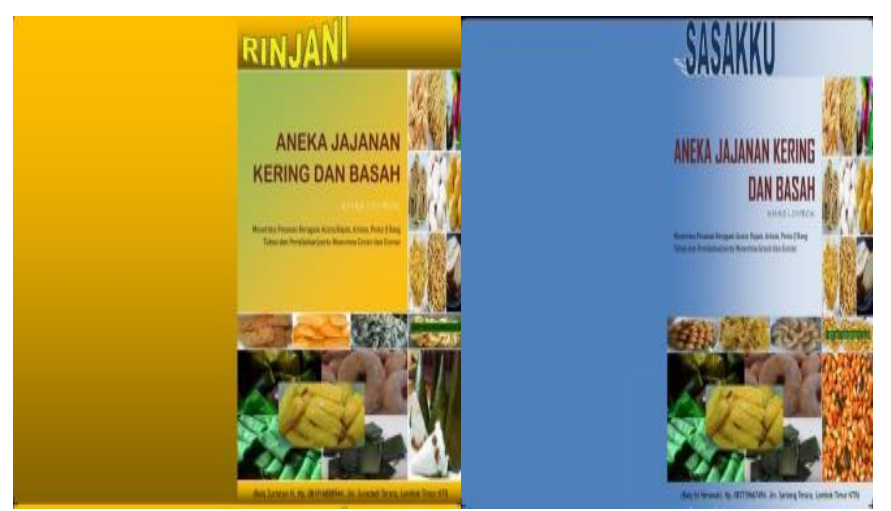

Gambar 5. Katalog Aneka Jajanan Khas Lombok Ukm Rinjani Dan Sasaskku

5. Terbitnya Perizinan Pangan Indutri Rumah Tangga (PIRT) untuk kedua mitra UKM RINJANI dan SASASKKU Penerbitan perizinan

Pangan Industri Rumah Tangga
(PIRT) bertujuan meningkatkan kepercayaan konsumen. Dengan adanya perijinan PIRT (Pangan Industri Rumah Tangga) maka 
dengan begitu usaha pangan olahan

lebih aman di konsumsi, dan dapat meningkatkan jaringan pemasaran.

Dokumentasi sertifikat PIRT yang sudah terbit untuk berbagai macam aneka jajanan khas Lombok yang di produksi oleh mitra UKM RINJANI dan UKM SASAKKU ditunjukkan pada Gambar 6 dibawah ini:

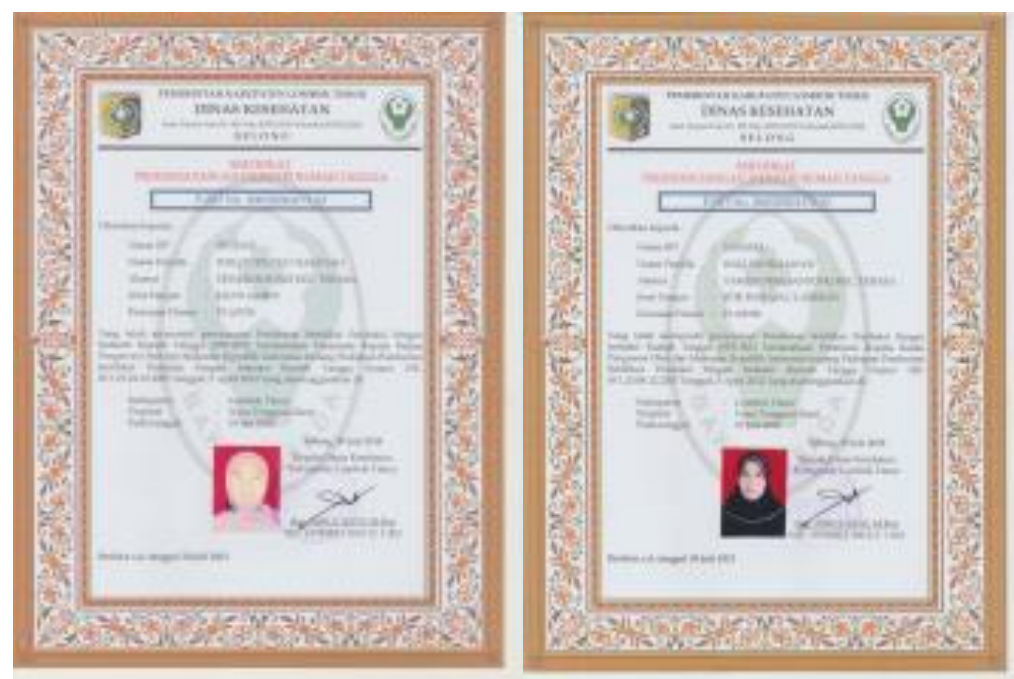

Gambar 6. Sertifikat PIRT Rinjani dan Sasakku

6. Penerbitan Sertifikat Halal Untuk Produk Kedua Mitra

Penerbitan sertifikat label halal MUI penting untuk membedakan dan mengetahui produk-produk yang dihasilkan oleh pelaku usaha termasuk UMK dalam pemenuhan Standar Kehalalan sebagai makanan yang sehat, aman dan proporsional. Dokumentasi sertifikat Halal MUI yang sudah terbit untuk aneka jajanan khas Lombok yang di produksi oleh mitra UKM RINJANI dan UKM SASAKKU ditunjukkan pada Gambar 7 dibawah ini: 


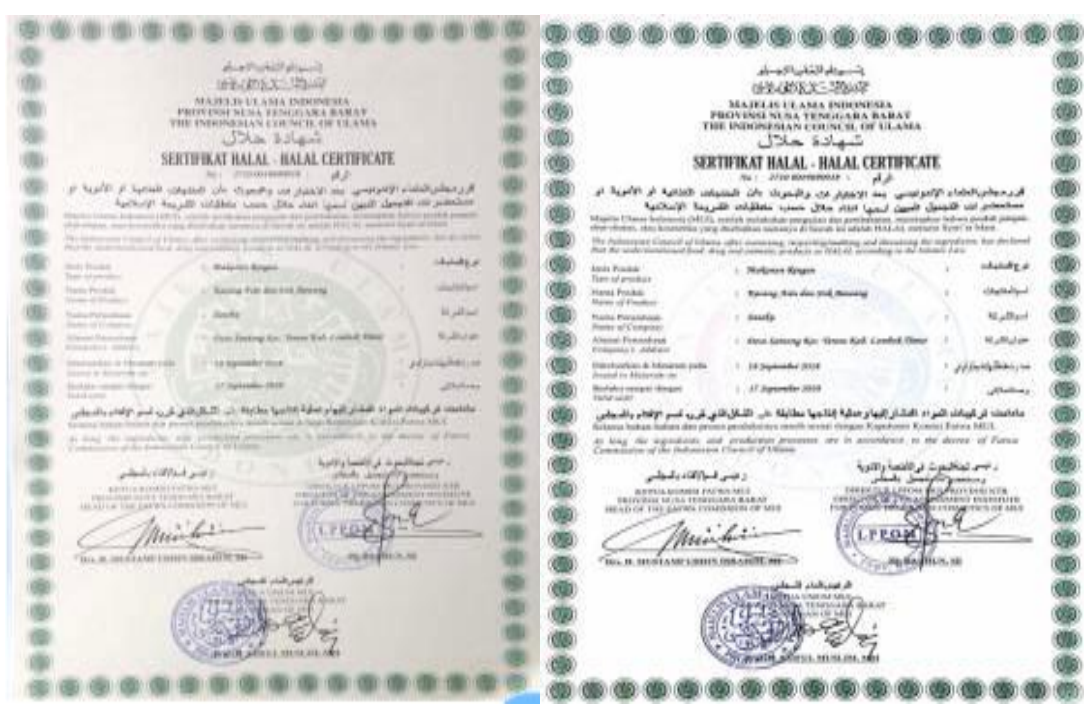

Gambar 7. Sertifikat Halal Produk Anek Jajanan Khas Lombok Mitra Ukm Rinjani Dan Sasakku

7. Blog sebagai Media Promosi Mitra RINJANI dan SASAKKU

Blog ini bisa dijadikan sebagai sarana yang efektif untuk memperluas jaringan pemasaran produk pangan olahan, sehingga calon konsumen bisa berhubungan langsung kepada para pengusaha mikro kecil, alamat blog Sasakku bisa membuka Link
Https://sasaklomboksnack.wordpress. com. Dan alamat blog Rinjani bias membuak

Link Https://rinjanisneclombok.wordpress.c om. Gambar blog kedua mitra ditunjukkan pada Gambar 8 dibawah ini. \begin{tabular}{l} 
ats saklomboksnack.wordpress.com $O$ : \\
Buat situs web Anda di WordPress.oom \\
\hline
\end{tabular}

\section{sasak lombok snack}

Jajan Tradisional Lombok

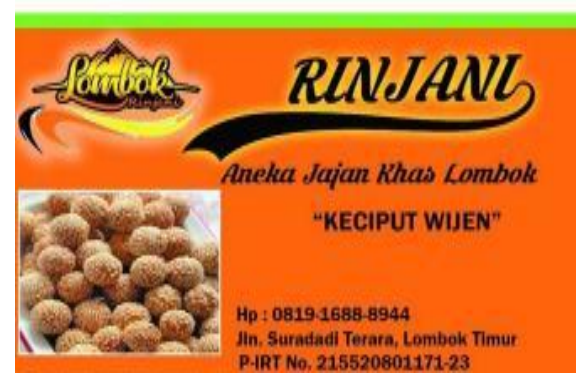

a janisnacklombok.wordpress.com $\circlearrowleft$;

Buat situs web Anda di WordPress.com

Memulai

IAJAN TRADISONAL LOMBOK

RINJANI SNACK LOMBOK

$\equiv$ MENU

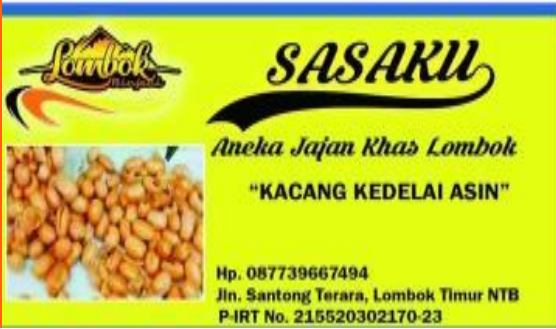
Jin. Santong Terara, Lombok Timur NTB
PIRT No. 215520302170-23

Gambar 8. Blog UKM Rinjani Dan Sasakku 
Setelah pelatihan selesai prakarsa, dan peningkatan disain dilaksanakan, peserta pelatihan produk, dengan tolok ukur diminta untuk memberikan penilaian keberhasilan $70 \%$.

dengan mengisi lembar evaluasi 3. Pelatihan disain grafis dan disain kegiatan program PKM. Penilaian katalog, meliputi 5 parameter dilakukan terhadap 3 aspek, yaitu:

\section{Penyelenggaraan}

pelatihan penilaian, yaitu: 1) kemampuan manajemen usaha, meliputi teknologi, peningkatan kreativitas, beberapa parameter penilaian, peningkatan keuletan, peningkatan yaitu: Peningkatan kreatifitas, prakarsa, dan peningkatan disain Peningkatan keuletan, Kemampuan produk, dengan tolok ukur keberhasilan 70\%. Range nilainya pembukuan, Peningkatan adalah dari 1 sampai dengan 5, keberanian beresiko, Peningkatan yaitu 1 (buruk), 2 (kurang), 3 Kewirausahaan, dengan tolok ukur keberhasilan $70 \%$.

2. Pelatihan disain grafis dan disain (cukup), 4 (baik), 5 (baik sekali). Hasil pengolahan data kuisioner ditunjukkan pada tabel 2 dibawah katalog, meliputi 5 parameter ini: penilaian, yaitu: kemampuan teknologi, peningkatan kreativitas, peningkatan keuletan, peningkatan 
Tabel 2. Hasil Pengolahan Kuisioner Evaluasi Kegiatan PKM

\begin{tabular}{|c|c|c|}
\hline Kegiatan & Indikator & Keberhasilan \\
\hline Pelatihan manajemen usaha & $\begin{array}{l}\text { a. Peningkatan kreatifitas } \\
\text { b. Peningkatan keuletan } \\
\text { c. Kemampuan pembukuan } \\
\text { d. Peningkatan keberanian } \\
\text { beresiko } \\
\text { e. Peningkatan Kewirausahaan }\end{array}$ & $84 \%$ \\
\hline $\begin{array}{l}\text { Pelatihan desain grafis (disain } \\
\text { kemasan dan katalog produk) }\end{array}$ & $\begin{array}{l}\text { a. Kemampuan Teknologi } \\
\text { b. Peningkatan kreatifitas } \\
\text { c. Peningkatan keuletan } \\
\text { d. Peningkatan prakarsa } \\
\text { e. Peningkatan desain produk }\end{array}$ & $80 \%$ \\
\hline $\begin{array}{l}\text { Pelatihan web dan } \\
\text { pemasaran }\end{array}$ & $\begin{array}{l}\text { a. Kemampuan Teknologi } \\
\text { b. Peningkatan kreatifitas } \\
\text { c. Peningkatan keuletan } \\
\text { d. Peningkatan prakarsa } \\
\text { e. Peningkatan pemasaran }\end{array}$ & $76 \%$ \\
\hline $\begin{array}{l}\text { Kepemilikan Nomer PIRT dan } \\
\text { Sertifikat Halal }\end{array}$ & $\begin{array}{l}\text { Penerbitan PIRT dan setifikat } \\
\text { Halal }\end{array}$ & $100 \%$ \\
\hline $\begin{array}{l}\text { Pembuatan Katalog Produk } \\
\text { aneka Jajanan Khas Lombok }\end{array}$ & $\begin{array}{l}\text { Katalog aneka jajanan khas } \\
\text { Lombok untuk UKM Rinjani } \\
\text { dan Sasakku }\end{array}$ & $100 \%$ \\
\hline
\end{tabular}

\section{KESIMPULAN}

Pelaksanaan pengabdian

kepada masyarakat pada skema Program Kemitraan Masyarakat (PKM) tahun anggaran 2018 meliputi tahapan pendahuluan,

perencanaan, pelaksanaan, dan pelaporan. Adapun kegiatan yang telah dilakukan :

1. Pelatihan yang dilakukan yakni: Pelatihan manajemen Usaha, Pelatihan manajemen keuangan, 3) Pelatihan web dan pemasaran 4) Sosialisasi keamanan pangan dan legalitas usaha, sangat membantu mitra memiliki pengetahuan dan keterampilan, menumbuhkan bahkan meningkatkan jiwa wirausaha.

2. Terbitnya PIRT untuk produk UKM Rinjani, dan label halal untuk UKM Rinjani dan Sasakku, ddengan begitu usaha pangan olahan lebih aman di konsumsi dan menjamin serta melindungi konsumen terhadap produk halal dan meningkatkan kepercayaan konnsumen.

3. Katalog aneka jajanan khas Lombok, dapat memudahkan konsumen dalam memilih aneka jajanan yang akan di pesan. 
4. Blog sebagai media pemasaran, dengan adanya blog dapat meningkatkan jaringan pemasaran dan memiliki jaringan yang lebih luas.

\section{UCAPAN TERIMAKASIH}

Terima kasih $\begin{array}{r}\text { kepada } \\ \text { Kemenristekdikti yang }\end{array}$
membiayai Hibah Pengabdian
Masyarakat pada skema Program
Kemitraan Masyarakat (PKM).

\section{DAFTAR PUSTAKA}

Agus

Pangestuti.,2016.

Setyaningrum

dan

pengembangan usaha kecil dan menengah (ukm) untuk meningkatkan citra kota malang sebagai destinasi wisata kuliner (studi pada ukm berbasis kuliner kota malang). Jurnal Administrasi Bisnis (JAB)|Vol. 38 No.2.

Badan Pusat Statistik Provinsi Nusa Tenggara Barat., 2016. Hasil Pendaftaran (listing) Usaha/Perusahaan Sensus Ekonomi 2016 provinsi nusa tenggara barat no. 36/05/52/th. I, 24 mei 2017

Fahrurrozi, M. 2017. Kewirausahaan untuk Calon Pebisnis UMKM. Bening Pustaka Yogyakarta.

Ekonomi NTB. Diklat Jaringan Usaha UMKM. (diakses file:///D:/Diklat Jaringan Usaha Ekonomi NTB.htm waktu selasa 6 juni 2017)

Hamid S.E dan Y. Sri Susilo., 2011. Strategi Pengembangan Usaha
Mikro Kecil Dan Menengah Di Provinsi Daerah Istimewa Yogyakarta. Jurnal Ekonomi Pembangunan Volume 12, Nomor 1, Juni 2011, hlm.45-55

Jaidan J., 2010. Upaya Pengembangan Usaha Kecil Dan Menengah (Ukm) Dengan Memanfaatkan ECommerce. Jurnal Sistem Informasi (JSI), VOL. 2, NO. 1, April 2010

Lantu C.D, dkk., 2016. Pengembangan Model Peningkatan Daya Saing UMKM di Indonesia: validasi kuantitatif model. Jurnal Manajemen Teknologi, 15(1), 2016,77-93

Majdi., Muhammad Zainul., 2012. Pengaruh pembelajaran kewirausahaan, internalisasi nilai kewirausahaan di keluarga dan motivasi minat kewirausahaan. http://e-

journal.hamzanwadi.ac.id/index.p hp/edc/article/view/130/107

Radar Lombok. Daya Saing Produk UMKM NTB Masih Lemah. (diakses file:///E:/Daya Saing Produk UMKM NTB Masih Lemah Portal Berita Harian Radar Lombok.htm waktu selasa 6 juni 2017)

Radar Lombok. Kemendag Dukung Peningkatan Produk UMKM. (diakses file:///D:/Mendorong Peningkatan PAD Melalui Penciptaan UMKM Bagi Pemuda Lombok Research Center.htm waktu selasa 6 juni 2017) 